DOI: https://doi.org/10.24127/ajpm.v9i3.2485

\title{
ANALISIS UJI KOMPETENSI GURU KABUPATEN BANGKA TENGAH TERHADAP HASIL UJIAN NASIONAL MATEMATIKA SISWA SMP
}

\author{
Vika Martahayu' ${ }^{1}$, Ayen Arsisari \\ ${ }^{1,2}$ STKIP Muhammadiyah Bangka Belitung, Bangka Belitung, Indonesia \\ E-mail: $\quad$ vika.martahayu@stkipmbb.ac.id ${ }^{1)}$ \\ ayen.arsisari@stkipmbbb.ac.id ${ }^{2}$
}

Received 05 March 2020; Received in revised form 11 June 2020; Accepted 10 September 2020

\begin{abstract}
Abstrak
Tujuan dari penelitian ini adalah untuk: (1) menghitung kompetensi guru Matematika tingkat SMP tahun 2015 di Bangka Tengah, (2) menghitung rata-rata nilai UN Matematika SMP tahun 2017, (3) menentukan korelasi antara hasil UKG guru Matematika terhadap hasil belajar Matematika siswa SMP pada UN tahun 2017. Metode yang digunakan adalah deskriprif kuantitatif. Subjek penelitian adalah guru dan siswa tingkat SMP. Waktu penelitian dilakukan di tahun 2019 selama 2 bulan yang berlokasi di Dinas Pendidikan Bangka dan beberapa SMP di Bangka Tengah. Teknik pengumpulan data yang digunakan yaitu wawancara, dan studi pustaka. Adapun hasil yang diperoleh yaitu rata-rata UKG guru ada pada kategori cukup yaitu pedagogik ada pada kategori tinggi dengan skor rata-rata 66,29 dan profesional ada pada kategori cukup dengan rata-rata 64,04. Untuk hasil ujian nasional kabupaten Bangka Tengah siswa SMP pada tahun 2017 diperoleh rata-rata 64,19. Hasil penelitian menunjukkan diperoleh nilai korelasi adalah 0,306. Nilai ini dapat diinterpretasikan bahwa hubungan kedua variabel penelitian lemah, selanjutnya diperoleh R Square atau koefisien determinasi (KD) sebesar 9,4\% yang dapat ditafsirkan bahwa hasil UKG di Kabupaten Bangka Tengah memiliki pengaruh kontribusi sebesar 9,4\% terhadap nilai UN siswa dan 90,6\% lainnya dipengaruhi oleh faktor-faktor lain, diantaranya minat, bakat kecerdasan intelektual, kecemasan, kesiapan mental dalam diri siswa.
\end{abstract}

Kata kunci: Matematika; ujian nasional; uji kompetensi guru.

\begin{abstract}
In this study, we want to see (1) the results of the mathematics teacher competency test in Central Bangka on the results of students' national exams in junior high school on mathematics subjects; (2) calculating the average value of the 2017 SMP Mathematics National Examination; (3) determining the correlation between the results of the UKG Mathematics teacher and the mathematics learning outcomes of junior high school students at the 2017 National Exam. The method used is quantitative descriptive. Research subjects were teachers and junior high school students. When the research was conducted in 2019 for 2 months located in the Bangka Education Office and several junior high schools in Central Bangka. Data collection techniques used were interviews, and literature study. As for the results obtained, the average $U K G$ of teachers is in the sufficient category, namely pedagogics in the high category with an average score of 66.29, and professionals in the moderate category with an average of 64.04. For the results of the Central Bangka district national examination, junior high school students in 2017 obtained an average of 64.19. The results showed the correlation value obtained was 0.306. This value can be interpreted that the relationship between the two research variables is weak, then obtained $R$ Square or a coefficient of determination (KD) of $9.4 \%$ which can be interpreted that the UKG results in Central Bangka Regency have a $9.4 \%$ contribution effect on students' UN scores and 90 Another $6 \%$ is influenced by other factors, including interest, intellectual intelligence, anxiety, mental readiness in students.
\end{abstract}

Keywords: Mathematics; national examination; teacher competency test.

This is an open access article under the Creative Commons Attribution 4.0 International License 
DOI: https://doi.org/10.24127/ajpm.v9i3.2485

\section{PENDAHULUAN}

Guru merupakan komponen yang paling berpengaruh terhadap terciptanya proses dan hasil pendidikan yang berkualitas. Oleh karena itu upaya perbaikan apapun yang dilakukan untuk meningkatkan kualitas pendidikan tidak akan memberikan sumbangan yang signifikan tanpa didukung oleh guru yang profesional dan berkualitas serta memiliki kinerja yang bagus (Inayati, 2016).

Guru yang profesional harus mampu mengusai pengetahuan yang mendalam berdasarkan spesialisainya (Lodang et al., 2013). Mampu mengembangkan diri sesuai dengan perkembangan ilmu pengetahuan dan teknologi serta seni. Keprofesionalan menjadi sumber nafkah kehidupan yang membutuhkan keahlian, kemahiran atau kecakapan yang memenuhi standar mutu dan norma tertentu. Kondisi atau situasi guru di masing-masing daerah berbeda, hal ini menyebabkan ketidaksamaan atau perbedaan dalam penguasaan kompetensi yang diharuskan.

Untuk mengetahui kondisi penguasaan kompetensi, harus dilakukan pemetaan kompetensi Guru. Pemetaan ini sudah dilaksanakan oleh Pemerintah melalui Uji Kompetensi Guru (UKG). UKG adalah dasar pertimbangan untuk pelaksanaan program pembinaan keprofesian berkelanjutan. Pasal 4 yang menegaskan bahwa guru sebagai agen pembelajaran berfungsi untuk meningkatkan mutu pendidikan nasional. Untuk dapat melaksanakan fungsinya dengan baik, guru wajib untuk memiliki syarat tertentu, salah satu diantaranya adalah kompetensi (Meutia \& Mursita, 2018). Kompetensi menurut UU No. 13/2003 tentang ketenagakerjaan: pasal 1 (10), "Kompetensi adalah kemampuan kerja setiap individu yang mencakup aspek pengetahuan, keterampilan dan sikap kerja yang sesuai dengan standar yang ditetapkan" (Nur, 2014).

Peran Guru merupakan faktor penentu yang sangat dominan dalam pendidikan pada umumnya, karena guru memegang peranan dalam proses pembelajaran, dimana proses pembelajaran merupakan inti dari proses pendidikan secara keseluruhan. Guru mempunyai

Sedangkan dalam penelitian ini UKG hanya terfokus pada kompetensi pedagogik dan profesional. Melalui hasil UKG tersebut untuk melihat korelasi hasil belajar pada UN tahun 2017 di Kabupaaten Bangka Tengah.

Pada Provinsi Bangka Belitung khususnya di Kabupaten Bangka Tengah sendiri masih banyak guru yang belum lulus tiap mata pelajaran yang di ujikan, hasil UKG tiap mata pelajaran masih tergolong rendah terutama dalam kompetensi pedagogik. Melalui hasil UKG tahun 2015 tiap mata pelajaran di Kab. Bangka Tengah identifikasi mengenai kelemahan dan profesional seorang guru dapat terlihat. Hasil UKG di Kab. Bangka Tengah rata-rata cukup baik, dengan hasil UKG yang maksimal seharusnya akan berdampak kepada hasil belajar siswa khususnya. Akan tetapi hasil belajar siswa khususnya pada mata pelajaran Matematika masih belum maksimal. Hasil belajar siswa dalam analisis ini akan dikaitkan melalui hasil Ujian Nasional pada mata pelajaran Matematika pada jenjang SMP tahun 2017 di Kabuapten Bangka Tengah.

Sejak tahun 2015, UN tidak lagi menjadi standar kelulusan. Kelulusan siswa di tentukan sepenuhnya oleh sekolah. Meski demikian, keberadaanya masih dianggap penting oleh pihak sekolah. Tujuan UN sepenuhnya untuk 
menilai pencapaian standar kompetensi lulusan pada mata pelajaran tertentu secara nasional. Hasil UN tersebut akan digunakan untuk pemetaan mutu, dasar seleksi masuk jenjang pendidikan selanjutnya, dan akan diberikan pembinaan (Sukarjo \& Sugiyanta, 2018).

Berbagai penelitian tentang UKG pernah dilakukan oleh peneliti terdahulu Sukarjo \& Sugiyanta (2018) tentang korelasi hasil UKG dengan UN Matematika SMA di Jogyakarta, Hermanto \& Santika (2016) tentang hasil UKG Matematika SMP di Tasikmalaya, Bakri \& Budi Raharjo (2015) tentang Analisis Uji Kompetensi Guru Fisika, Dardiri, Mujiono, Dardiri et al. (2017) tentang analisis UKG SMK bidang keahlian Teknik Bagunan. Izwanto (2016) Peta Kompetensi Guru Matematika SMP di Kabupaten Bengkulu Berdasarkan Hasil UKG Tahun 2015, (Murtadho et al., 2015) tentang hubungan UKG dengan UN Geografi SMA di Semarang. Namun untuk daerah kepulauan Bangka Belitung khususnya Kabupaten Bangka Tengah belum ada yang meneliti hasil UKG.

Kabupaten Bangka Tengah sendiri masihbanyak guru yang belum lulus tiap mata pelajaran yang di ujikan, Hasil UKG tiap mata pelajaranmasih banyak nilai yang rendah diperoleh terutama dalam kompetensi pedagogik. Melalui hasil UKG tahun 2017 tiap mata pelajaran di Kab. Bangka Tengah identifikasi mengenai kelemahandan profesional seorang guru dapat terlihat. Hasil UKG di Kab. Bangka Tengah rata-rata cukup baik, dengan hasil UKG yang maksimal seharusnya akan berdampak kepada hasil belajar siswa khususnya. Akan tetapi hasil belajar siswa khususnya pada mata pelajaran Matematika masihbelum maksimal. Hasil belajar siswa dalam analisis ini akan dikaitkan melalui hasil Ujian Nasionalpada mata pelajaran Matematika pada jenjang SMP tahun 2017 di provinsi DI Kab. BangkaTengah.

Pada penelitian ini akan dilihat UKG mata pelajaran Matematika terhadap hasil belajar Matematika pada UN tahun 2017. Penelitian ini bertujuan untuk mengetahui Kompetensi guru pada mata pelajaran Matematika tahun 2017 di Kab. Bangka Tengah, rata-rata nilai Ujian Nasional pada mata pelajaran Matematika tahun 2017, untuk mengetahui Kompetensi Guru Terhadap hasil Ujian Nasional pada mata pelajaran Matematika tahun 2017 di SMP Kab. Bangka Tengah. Diharapkandengan hasil analisis UKG ini dapat menjadi acuan pemerintah dalam meningkatkan ujian nasional khususnya mata pelajaran Matematika.

\section{METODE PENELITIAN}

Penelitian ini menggunakan pendekatan deskriptif kuantitatif. Untuk kepentingan dengan fokus data hasil Uji Kompetensi Guru (UKG) mata pelajaran Matematika di Kabupaten Bangka Tengah serta hasil Ujian Nasional (UN) pada mata pelajaran Matematika siswa SMP. Dengan metode ini dimaksudkan untuk memberikan gambaran yang jelas tentang komptensi guru mata pelajaran dengan hasil ujian nasional siswa pada mata pelajaran matematika. Data hasil penelitian yang digunakan adalah data primer dan sekunder dari hasil UKG mata pelajaran Matematika dan Hasil UN pada mata pelajaran Matematika pada tingkat SMP di Kabupaten Bangka Tengah. Kerangka penelitian dapat dilihat pada Gambar 1. 
DOI: https://doi.org/10.24127/ajpm.v9i3.2485

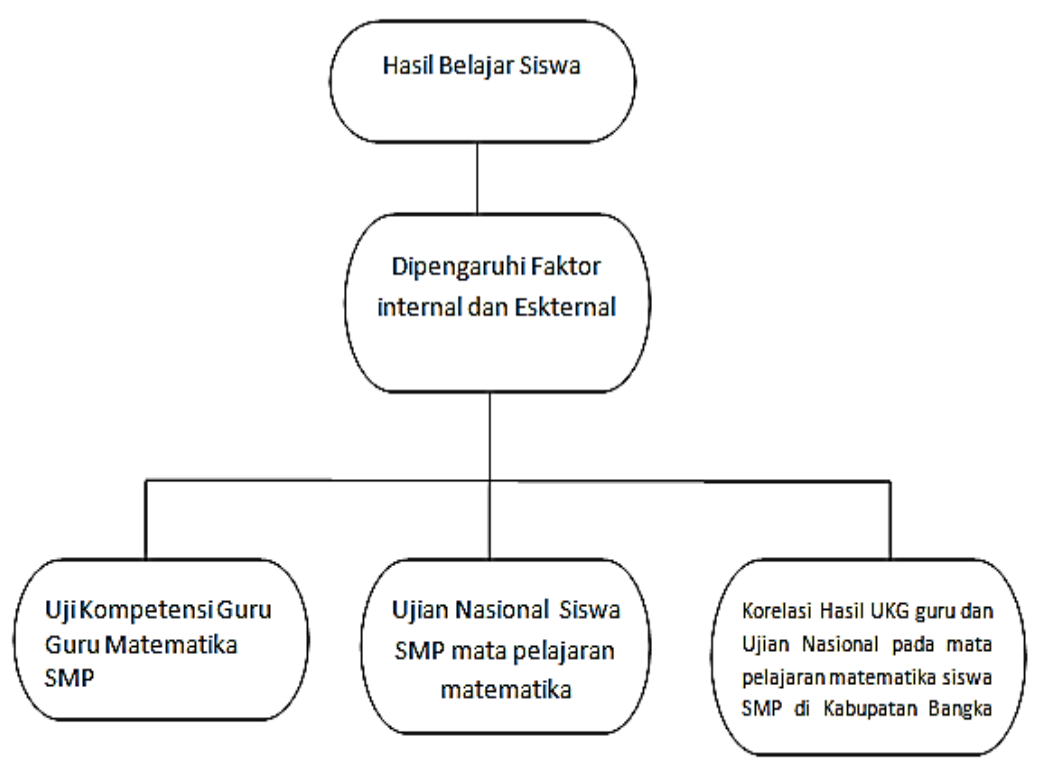

Gambar 1. Kerangka Penelitian

Penelitian ini dilakukan di Dinas

Pendidikan Bangka Tengah Provinsi Kepulauan Bangka Belitung dan Beberapa sekolah menengah pertama di Kabupaten Bangka Tengah. Populasi yang digunakan adalah seluruh guru mata pelajaran matematika tingkat SMP di Kabupaten Bangka Tengah yang berjumlah 47 dan seluruh siswa yang mengikuti ujian nasional tingkat SMP mata pelajaran matematika di Kabupaten Bangka Tengah tahun 2017 berjumlah 2053. Sampel penelitian ini adalah seluruh guru mata pelajaran tingkat SMP di Kabupaten Bangka Tengah dan seluruh siswa yang mengikuti ujian nasional tingkat SMP di Kabupaten Bangka Tengah tahun 2017 pada mata pelajaran matematika, istilah lain sampel yang digunakan sampel jenuh.

Pengumpulan data yang dilakukan adalah gambaran Uji Kompetensi Guru (UKG) tahun 2015 hasil belajar siswa SMP pada UN mata pelajaran matematika tahun 2017 di kabupaten Bangka Tengah, dokumentasi dan studi kepustakaan.
Studi kepustakaan yaitu melakukan studi melalui buku-buku kepustakaan atau bahan yang tersedia dilingkungan Dinas Pendidikan Bangka Tengah baik berupa informasi yang tersedia dilaporan hasil ujian kompetensi guru, hasil ujian nasional, data penelitian serta wawancara yang dilakukan secara tidak terstruktur dilakukan kepada guru matematika di Kabupaten Bangka Tengah.

Teknik analisis data akan menggunakan teknik statistik deskriptif dan inferensial yaitu deskripsi hasil rata-rata nilai UN dan Uji Kompetensi Guru (UKG). Selanjutnya akan dgunakan uji korelasi menggunakan korelasi product moment dan regresi Sederhana dengan bantuan program SPSS 18. Adapun variablnya yaitu hasil ujian nasional siswa tahun 2017 dan hasil ujian kompetensi guru tahun 2015 Hal ini untuk menunjukkan korelasi antara nilai UN dan UKG guru pada mata pelajaran matematika dan seberapa besar pengaruh ataupun kontribusi nilai UKG terhadap hasil UNmata pelajaran matematika siswa tingkat SMP. 
DOI: https://doi.org/10.24127/ajpm.v9i3.2485

\section{HASIL DAN PEMBAHASAN}

1. Data UN Mata Pelajaran Matematika Perkecamatan di Kabupaten Bangka Tengah Tahun 2017

Data nilai ujian nasional matematika untuk setiap kecamatan di kabupaen Bangka Tengah dapat dilihat pada Tabel 1. Berdasarkan informasi pada tabel 1 di atas diperoleh bahwa nilai rata-rata UN tertinggi di raih oleh kecamatan Koba dengan rata-rata 43,27, selanjutnya dari kecamatan Simpang Katis dengan rata-rata nilai 41,07, peringkat ketiga dari kecamatan Pangklanbaru dengan rata-rata nilai sebesar 39,93, peringkat keempat oleh kecamatan Namang dengan rata-rata nilai 39,89, selanjutnya dari kecamatan Sungai Selan dengan rata-rata nilai 39,01 dan terakhir ditempati oleh kecamatan Lubuk Besar dengan ratarata nilai sebesar 37,62.Secara keseluruhan rata-rata nilai ujian nasional siswa yaitu 34,2. Jika dilihat dari data pada Tabel 1, perlu kerjakeras semua pihak dalam meningkatkan hasil belajar siswa pada mata pelajaran matematika. Walaupun sebenarnya skor 34,2 bukanlah menjadi patokan secara keselurahan bahwa hasil belajar siswa rendah. Setidaknya dalam beberapa siswa yang peneliti temukan hampir $24 \%$ siswa memiliki nilai UN di atas 60 . Karena ada input dan proses yang berbeda untuk tiap-tiap masing-masing sekolah kemudian di standarkan dengan diberikan soal-soal ujian nasioanal dengan bobot yang sama. (Nurul, 2013) mengatakan jikapun ujian nasioanal harus dipertahankan, tentunya tetap dalma koridor membentuk standar sebagai comparative advantage dalam dunia yang semkain kompetitif. Sehingga dimanapun anak didik kita dapat bersaing dan bersanding dalam memenuhi haknya sebagai sebagai warga dalam mendapatkan kesempatan memperoleh pendidikan, tanpa dipandang sebelah mata karena berasal dari daerah atau provinsi yang dianggap bermutu. Disinilah standarisasi menjaid kata kunci menuju pendidikan indonesia yang cerdas dan berkualitas.

Tabel 1. Nilai Rata-rata UN siswa perkecamatan di Kabupaten Bangka Tengah Tahun 2017

\begin{tabular}{ccc}
\hline Kecamatan & Nilai Rata-rata & Rangking \\
\hline Koba & 43,27 & 1 \\
Lubuk Besar & 37,62 & 6 \\
Namang & 39,89 & 4 \\
Pangkalan Baru & 39,93 & 3 \\
Simpang Katis & 41,07 & 2 \\
Sungai Selan & 39,01 & 5 \\
\hline
\end{tabular}

2. Hasil Uji UKG Mata Pelajaran Matematika

Hasil uji UKG yang diujikan untuk melihat kompetensi profesional dan pedagogic guru. Adapun hasil UKG guru matematika di kabupaten Bangka Tengah secara keseluruhan di analisis dan diperoleh hasil seperti yang ditunjukkan pada Tabel 2. 
DOI: https://doi.org/10.24127/ajpm.v9i3.2485

Tabel 2. Hasil UKG Guru SMP matematika di Bangka Tengah pada Tahun 2015

\begin{tabular}{cccc}
\hline No & Kompetensi & Rata-rata & Kategori \\
\hline 1 & Pedagogik & 66,29 & Cukup \\
2 & Profesional & 64,04 & Cukup \\
\hline
\end{tabular}

Berdasarkan data pada Tabel 2, hasil uji kompetensi guru (UKG) guru ada pada kategori cukup yaitu pedagogik ada pada kategori tinggi dengan skor ratarata 66,29 dan profesional ada pada kategori cukup dengan rata-rata 64,04.

Pada ranah pedagogik ini sebagai bentuk dari semua usaha yang dilakukan oleh pendidik untuk membimbing seorang anak menjadi manusia dewasa yang matang. Peran pendidik di sekolah digantikan oleh guru sehingga terjadi pergeseran tuntutan kemampuan pedagogik. Keadaan ini menjadikan tugas guru tidak cukup sebagai pengajar yang berfokus pada transfer ilmu pengetahuan, namun meluas pada ranah non akademis.Bila dilihat hasil UKG guru matematika tingkat SMP kabupaten Bangka Tengah sudah cukup baik, namun tidak hanya cukup berbangga hati dengan skor yang diperoleh perlu adanya inovasi dan keterampilan yang perlu ditingkatkan untuk menghadapi perubahan yang terjadi.

Pada kompetensi profesional dengan rata-rata 64,04 ini merupakan sebuah hasil yang cukup. Guru matematika tingkat SMP pada mata pelajaran telah memiliki penguasaan materi dan konsep cukup baik kompetensi profesional yang dapat diukur meliputi penguasaan materi, konsep dan pola pikir keilmuan, menguasai standar kompetensi dan kompetensi dasar mata pelajaran dan pengembangan materi pembelajaran sesuai dengan kompetensi yang akan dicapai.
Kompetensi profesional perlu untuk terus ditingkatkan. Hasil kompetensi profesioanal tidak serta merta pada skor 64,04 namun ada sekitar38\% guru memiliki skor di atas 64,04 dan hal ini memberikan padangan guru-guru di Bangka Tengah memiliki kompetensi profesional yang cukup baik, namun tidak bisa juga pungkiri hampir 26\% guru memiliki kemampuan profesional di bawah rata-rata. Hal ini berdasarkan hasil wawancara kepada beberapa guru, faktor-faktor yang mempengaruhi yaitu penguasaan teknologi dan tidak meratanya informasi tentang pelaksanaan UKG sehingga kesiapan guru ketika mengikuti tes masih kurang. Ini artinya harus perlu ditingkatkan mengingat nilai UN siswa pada mata pelajaran matematika masih perlu ditingkatkan. Walaupun sebenarnya ada faktor lain yang mempengaruhi hasil belajar siswa, namun guru juga menjadi faktor yang cukup penting dalam menentukan hasil balajar siswa. Nilai rata-rata pada tiap kompetensi dapat dilihat pada histogram yang disajikan pada Gambar 2.

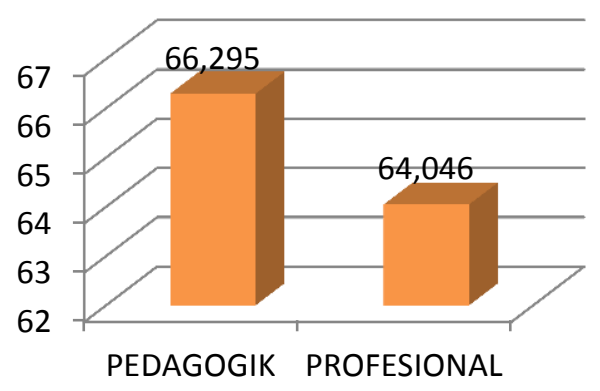

Gambar 2. Hasil UKG mata pelajaran matematika tahun 2015 
DOI: https://doi.org/10.24127/ajpm.v9i3.2485

Data selanjutnya tentang persentase kategori hasil UKG untuk kompetensi pedagogik mata pelajaran matematika dapat dilihat pada Gambar 3.

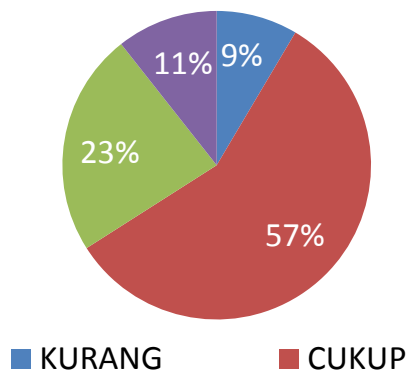

Gambar 3. Persentase kategori hasil

UKG pada kompetensi pedagogik mata pelajaran matematika tahun 2015.

Berdasarkan Gambar 3 dapat dilihat $34 \%$ guru memiliki kompetensi pedagogik di atas kategori cukup, 57\% berada pada kategori cukup dan 9\% berada apda ketegori kurang. Angkaangka ini memberikan gambaran bahwa kompetensi pedagogik guru-guru di Bangka Tengah cukup baik hal ini diharapkan mampu memberikan kontribusi yang baik terhadap hasil belajara siswa khususnya pada mata pelajaran matematika.

Selanjutnya, rincian persentase untuk kompetensi profesional guru matematika pada digaram lingkaran yang disajikan pada Gambar 4. Diperoleh gambaran bahwa $38 \%$ kompetensi profesional guru di atas kategori cukup, $36 \%$ cukup dan $26 \%$ berada pada kategori kurang. Jika dibandingkan dengan kemampuan pedagogik yang hanya memiliki $9 \%$ maka guru-guru pada mata pelajaran matematika harus lebih meningkatkan kompetensi profesional. Hal ini sesusi dengan hasil penelitian yang dilakukan oleh (Dudung, 2018) mengatakan bahwa diperlukan penguatan kompetensi professional guru dengan upaya-upaya yang perlu dilakukan untuk meningkatkan kompetensi profesional guru diantaranya pendidikan dan pelatihan yang berkaitan dengan penguasaan materi sekolah, mengoptimalkan wadah musyawarah guru mata pelajaran (MGMP) sebagai wadah komunikasi dan pendalaman materi-materi, serta terus mengoptimalkan penguasaan materi ajar, maka guru akan memiliki wawasan yang luas dan mendalam sehingga dapat membelajarkan siswa dengan baik.

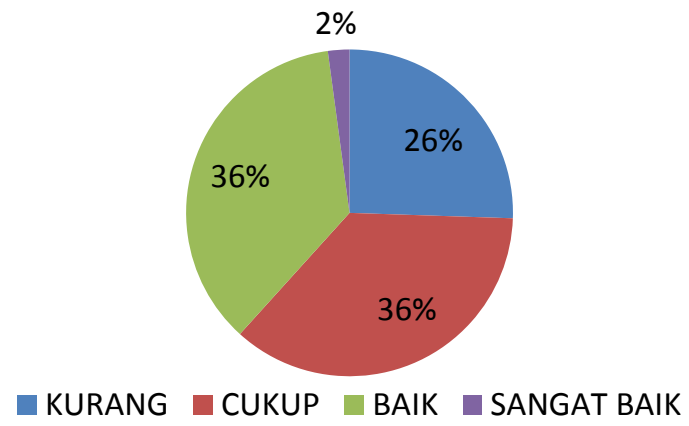

Gambar 4. Persentase kategori hasil

UKG pada kompetensi profesional.

Selanjutnya, data ranking sekolah berdasarkan nilai UKG tahun 2015 disajikan dalam Tabel 3. Berdasarakan informasi pada Tabel 3, diperoleh bahwa nilai rata-rata UKG tertinggi diraih oleh kecamatan Koba dengan rata-rata 71,45, selanjutnya dari kecamatan Pangklanbaru dengan ratarata 69,66 , peringkat ketiga dari kecamatan Sungai Selan dengan ratarata 64,59, peringkat keempat oleh kecamatan Namang dengan rata-rata 64,28, selanjutnya dari kecamatan Simpang Katis dengan rata-rata 62,74 dan terakhir ditempati oleh kecamatan Lubuk Besar dengan rata-rata 52,43. Sebenarnya jika dilihat dari kemampuan rata-rata tiap kecamatan, selisih nilai rata-rata antar kecamatan tidak terlalu jauh kecuali antara Kecamatan Koba dan Lubuk besar. Namun secara keseluruhan memang perlu peningkatan 
DOI: https://doi.org/10.24127/ajpm.v9i3.2485

kompetensi untuk tiap-tiap kecamatan. Guru pada tiap satuan pendidikan harus memenuhi kualifikasi akademik dengan bidang keilmuan yang relevan dengan bidang studi atau mata pelajaran yang mereka ajarkan di sekolahnya sehingga mereka disebut kompeten untuk bidang pekerjaannya. Guru yang kompeten akan lebih mampu menciptakan lingkungan belajar yang efektif, menyenangkan dan lebih mampu mengelola kelasnya sehingga hasil belajar siswa juga baik (Umu et al., 2018).

Tabel 3. Ranking sekolah berdasarkan nilai UKG Tahun 2015

\begin{tabular}{ccccc}
\hline Kecamatan & Nilai Tertinggi & \multicolumn{2}{c}{ Nilai Terendah } & \multicolumn{2}{c}{ Nilai Rata } & RANK \\
\hline Koba & $\mathbf{8 1 , 3 4}$ (SMP N 1 Koba) & $\mathbf{5 9 , 5 2}$ (SMP N 1 Koba) & $\mathbf{7 1 , 4 5}$ & 1 \\
Lubuk Besar & $\mathbf{7 1 , 4 2}$ (SMP N 1 Lubuk Besar) & $\mathbf{3 5 , 7 1}$ (SMP N 2 Lubuk Besar) & $\mathbf{5 2 , 4 3}$ & 6 \\
Namang & $\mathbf{7 9 , 3 6}$ (SMP N 1 Namang) & $\mathbf{5 3 , 5 7}$ (SMP N 1 Namang) & $\mathbf{6 4 , 2 8}$ & 4 \\
Pangkalan Baru & $\mathbf{8 7 , 3 0}$ (SMP N 3 Pangkalanbaru) & $\mathbf{5 5 , 5 5}$ (SMP N 1 Pangkalanbaru) & $\mathbf{6 9 , 6 6}$ & 2 \\
Simpang Katis & $\mathbf{6 9 , 4 4}$ (SMP N 1 \& SMP N 2 & $\mathbf{5 1 , 5 8}$ (SMP N 1 Simpang Katis) & $\mathbf{6 2 , 7 4}$ & 5 \\
Simpang Katis) & $\mathbf{4 3 , 6 5}$ (SMP N 3 Satu Atap & $\mathbf{6 4 , 5 9}$ & 3 \\
\hline
\end{tabular}

3. Gambaran Hasil UKG Matematika SMP dan UN Pada Mata Pelajaran Matematika Tingkat SMP Kabupaten Bangka Tengah Tahun 2017.

Gambaran dari hasil uji kompetensi guru (UKG) Matematika SMP dan nilai ujian nasional (UN) mata pelajaran mateamtika tingkat SMP di kabupaten Bangka Tengah pada tahun 2017 secara korelasional dapat dilihat pada Tabel 4.

Tabel 4. Hasil perhitungan korelasi antara nilai UKG dan UN pada mata pelajaran matematika.

\begin{tabular}{rrrrr}
\hline Model & $\mathbf{R}$ & $\begin{array}{c}\text { R } \\
\text { Square }\end{array}$ & $\begin{array}{c}\text { Adjusted R } \\
\text { Square }\end{array}$ & $\begin{array}{l}\text { Std. Error of } \\
\text { the Estimate }\end{array}$ \\
\hline 1 &, $306^{\mathrm{a}}$ &, 094 &, 049 & 3,55140 \\
\hline
\end{tabular}

Pada Tabel 4 ditampilkan nilai $\mathrm{R}$ yang merupakan simbol dari nilai koefisien korelasi. Pada tabel 4 diperoleh nilai korelasi adalah 0,306. Nilai ini dapat diinterpretasikan bahwa hubungan kedua variabel penelitian lemah. Melalui tabel ini juga diperoleh nilai $\mathrm{R}$ Square atau koefisien determinasi (KD) yang menunjukkan seberapa bagus model regresi yang dibentuk oleh interaksi variabel bebas dan variabel terikat. Nilai KD yang diperoleh adalah 9,4\% yang dapat ditafsirkan bahwa hasil UKG di Kabupaten Bangka Tengah memiliki pengaruh kontribusi sebesar 9,4\% terhadap nilai UN siswa dan 90,6\% lainnya dipengaruhi oleh faktor-faktor lain.

Bila dilihat dari hasil persentase sangat kecil pengaruh faktor eksternal salah satunya kompetnsi guru terhadap hasil ujian nasional siswa. Hal ini dimungkinkan ada berbagai faktor lainyang mempengaruhinya yaitu faktor internal misalkan bakat, minat, kecerdasan intelektual, kecemasan, kesiapan mental siswa dalam diri siswa hal ini juga di dukung pernyataan dari (Srinalia, 2015) menyebutkan bahwa dalam proses belajar mengajar di kelas, tidak setiap siswa dalam dirinya memiliki motivasi intrinsit, yakni kesadaran sendiri untuk memperhatikan penjelasan guru, rasa ingin tahu lebih banyak terhadap materi yang diberikan guru. Dalam pertemuan di kelas ada 
juga siswa yang tidak ada motivasi dalam dirinya (intrinsik), masalah inilah yang dihadapi guru. Demikian pula dengan motivasi ekstrinsit. Hal lain juga didukung oleh Valiant \& Siswanto (2016) yang mengatakan bahwa guru yang dapat menguasai metode mengajar praktik yang baik maka guru tersebut idealnya akan dapat menumbuhkan motivasi belajar siswa terlebih dahulu teruta-ma pada tahap persiapan sehingga para siswa sudah siap dan antusias untuk memulai pem-belajaran. Siswa yang sudah termotivasi akan lebih mudah dan siap dalam menerima pel-ajaran yang diberikan oleh guru. dengan demikian kedua motivasi diperlukan agar terjadi kesinambungan dalam proses belajar mengajar.

\section{KESIMPULAN DAN SARAN}

Simpulan dari penelitian adalah (1) diperoleh gambaran rata-rata ujian nasional siswa di Kabupaten Bangka Tengah pada tahun 2017 sebesar 64,19; (2) untuk hasil yang diperoleh yaitu rata-rata UKG guru ada pada kategori cukup yaitu pedagogik ada pada kategori tinggi dengan skor rata-rata 66,29 dan profesional ada pada kategori cukup dengan rata-rata 64,04 ; (3) menentukan korelasi antara hasil UKG guru Matematika terhadap hasil belajar Matematika siswa SMP pada UN tahun 2017. Berdasarkan hasil tersebut menunjukkan nilai korelasi adalah 0,306, diinterpretasikan bahwa hubungan kedua variabel penelitian lemah, selanjutnya diperoleh $\mathrm{R}$ Square atau koefisien determinasi (KD) sebesar 9,4\% yang dapat ditafsirkan bahwa hasil UKG di Kabupaten Bangka Tengah memiliki pengaruh kontribusi sebesar 9,4\% terhadap nilai UN siswa dan $90,6 \%$ lainnya dipengaruhi oleh faktor-faktor lainnya diantaranya minat, bakat kecerdasan intelektual, kecemasan, kesiapan mental dalam diri siswa.

Berdasarkan dari hasil penelitian yang dilakukan adapun saran yang dapat diberikan oleh peneliti, perlu adanya peningkatan dan usaha yang lebih bagi guru matematika dan juga praktisi pendidikan khususnya dibidang matematika untuk meingkatkan hasil belajar. Serta perlu adanya peningkatan kompetensi guru walaupun berdasarkan hasil UKG ada pada katagori cukup, namun masih perlu adanya peningkatan kompetensi guru agar memberikan kontribusi yang baik terhadap pengajaran. Keberhasilan hasil belajar tentunya dikarena kolaborasi yang seimbang antara faktor internal dan eksternal.

\section{DAFTAR PUSTAKA}

Bakri, F., \& Budi Raharjo, S. (2015). Analisis Hasil Uji Kompetensi Guru Fisika. JPPPF: Jurnal Penelitian \& Pengembangan Pendidikan Fisika, 01(1), 91-96. https://doi.org/10.21009/1.01113

Dardiri, A., Mujiyono, M., \& Ichwanto, M. A. (2017). Analisis Hasil Uji Kompetensi Guru Sekolah Menengah Kejuran Bidang Keahlian Teknik Bangunan. Teknologi Dan Kejuruan: Jurnal Teknologi, Kejuruan, Dan Pengajarannya, 40(2), 193-203. https://doi.org/10.17977/um031v40 i22017p193

Dudung, A. (2018). Kompetensi Profesional Guru. JKKP (Jurnal Kesejahteraan Keluarga Dan Pendidikan), 5(1), 9-19. https://doi.org/10.21009/jkkp.051.0 2

Hermanto, R., \& Santika, S. (2016). Analisis hasil uji kompetensi guru matematika sekolah menengah 
DOI: https://doi.org/10.24127/ajpm.v9i3.2485

pertama ( SMP ) di Kota Tasikmalaya. JP3M: Jurnal Penelitian Pendidikan Dan Pengajaran Matematika, 2(2), 135-142.

Inayati, N. L. (2016). Peran Kepala Sekolah dalam Meningkatkan Profesionalisme Guru di Sekolah Menengah Pertama (SMP) Muhammadiyah 6 Kendal Tahun Ajaran 2013/2014. SUHUF, 28(2), 175-191.

Izwanto, E. (2016). Peta kompetensi guru matematika SMP di kabupaten Bengkulu tengah berdasarkan hasil UKG tahun 2015. Jurnal Pendidikan Matematika Raflesia, 3(2), 30-40.

Lodang, H., Azis, A. A., Palennari, M., \& Ardiansyah, R. (2013). Analisis kompetensi profesional guru biologi sekolah menengah atas negeri di kota makassar. Jurnal Bionature, 14(1), 25-32.

Meutia, V., \& Mursita, R. A. (2018). Kompetensi Pedagogik Guru Kelas Dalam Pembelajaran Peserta Didik Tunarungu. Cakrawala Dini: Jurnal Pendidikan Anak Usia Dini, 9(1), 19-27. https://ejournal.upi.edu/index.php/ cakrawaladini

Murtadho, Juhadi, \& Santoso, A. B. (2015). Hubungan Antara Nilai Uji Kompetensi Guru (UKG) dengan Nilai Rata-Rata Ujian Nasional Mata Pelajaran Geografi Tahun 2013 di SMA Se Kota Semarang. Edu Geography, 3(7), 9-15.

Nur, A. A. (2014). Meningkatkan Kompetensi Pedagogik Guru di SD Yayasan Mutiara Gambut. Jurnal Administrasi Pendidikan, 2(1), 6572.

ejournal.unp.ac.id/index.php/bahan a/article/viewFile/3735/2970

Nurul, H. (2013). Ujian Nasional Dalam
Perspektif Kebijakan Publik. Jurnal Pencerahan, 7(1). http://jurnal.unsyiah.ac.id/index.ph p/index/oai

Srinalia. (2015). Faktor-faktor Penyebab Rendahnya Kinerja Guru dan Korelasinya terhadap Pembinaan Siswa: Studi Kasus di SMAN Darul Imarah Aceh Besar. Jurnal Ilmiah Didaktika Media Ilmiah Pendidikan, 15(2), 193207.

https://jurnal.arraniry.ac.id/index.p hp/didaktika/article/view/580/483

Sukarjo, M., \& Sugiyanta, I. (2018). Korelasi Hasil UKG SMA Tahun 2015 dengan Hasil UN Matematika SMA tahun 2016 Daerah Istimewa Yogyakarta. Jurnal Teknologi Pendidikan, 20(1), 60-72.

Umu, S., Bambang, S., \& Hety. (2018). Pengaruh Kompetensi Guru Terhadap Hasil Belajar Ekonomi di SMA Negeri Rambipuji Tahun Ajaran 2017/2018. Jurnal Pendidikan Ekonomi: Jurnal Ilmiah Ilmu Pendidikan, Ilmu Ekonomi \& Ilmu Sosial, 12(2). https://doi.org/10.19184/jpe.v12i2. 8316

Valiant, L., \& Siswanto, B. T. (2016). Faktor-faktor Yang Mempengaruhi Hasil Belajar Siswa Pada Pembelajaran Praktik Kelistrikan Otomotif SMK di Kota Yogyakarta. Jurnal Pendidikan Vokasi, 6(1), 111-120. http://journal.uny.ac.id/index.php/j pv 